E-ISSN : 2549-6581

DOI: 10.21776/ub.JOIM.2020.004.02.1

Artikel Hasil Penelitian

Diterima : 2 Juli 2018

Direview : 16 Oktober 2019

Dimuat : Agustus - November 2020

\title{
Pengaruh Pemberian Kompres Daun Kubis Dingin sebagai Terapi Pendamping Bendungan ASI terhadap Skala Pembengkakan dan Intensitas Nyeri Payudara serta Jumlah ASI pada Ibu Postpartum di RSUD Bangil
}

\author{
Ervi Damayanti ${ }^{1 *}$, Dewi Ariani ${ }^{2}$, Danik Agustin ${ }^{3}$ \\ $\left.1^{*}\right)$ Program Studi Kebidanan Fakultas Kedokteran Universitas Brawijaya, email : \\ ervidamayantii@gmail.com, Tlp : +6285747929525 \\ 2 Program Studi Pendidikan Profesi Bidan Fakultas Kedokteran Universitas Brawijaya \\ ${ }^{3}$ Laboratorium Anatomi Fakultas Kedokteran Universitas Brawijaya
}

\begin{abstract}
Breast engorgement is a common problem in early postpartum, causing discomfort to become one of the obstacles in exclusive breastfeeding. Therefore, an effective method is needed to solve this problem. This study aimed to determine the effect of cold cabbage leaf compression on the engorgement scale and breast pain intensity, and the amount of breast milk in postpartum mothers. This study was Quasy Experimental with pre-test posttest with control group design, with 32 samples of postpartum mothers with breast engorgement, divided into two groups (intervention and control), with sampling technique of quota sampling. The data collection used a questionnaire sheet containing Six Point Engorgement Scale, Numeric Ratting Scale/NRS. Analysis of this study using Wilcoxon and Mann-Whitney test. The results showed that the compression of cold cabbage leaves had a significant effect on the decrease of engorgement scale and the intensity of pain, and increase of breastmilk with p-value of $0.000(\alpha<0,05)$, the control group (hand expression) also had significant influence on engorgement scale and the intensity of pain, and the amount of breastmilk with $p$-value $\alpha<0,05$. There were significant differences in both groups in reducing engorgement and pain intensity ( $p$-value <0.005), but in increasing the amount of breast milk did not show a significant difference between the two groups ( $p$-value 0.344). The conclusion of this study is cold cabbage leaf compresses can be used as a therapy to reduce the scale of engorgement and the intensity of breast pain in mothers with breast engorgement.
\end{abstract}

Keywords: Breast engorgement scale, Intensity of breast pain, Amount of breast milk, Compress cold cabbage leaves, Hand expression

\begin{abstract}
ABSTRAK
Bendungan ASI merupakan masalah yang sering terjadi pada awal postpartum, yang dapat menimbulkan ketidaknyamanan sehingga menjadi salah satu hambatan dalam pemberian ASI eksklusif. Oleh karena itu, diperlukan metode yang efektif dalam mengatasi masalah ini. Penelitian ini bertujuan untuk mengetahui pengaruh pemberian kompres daun kubis dingin terhadap skala pembengkakan dan intensitas nyeri payudara, serta jumlah ASI pada ibu postpartum dengan bendungan ASI. Jenis penelitian ini adalah Quasy Eksperimental dengan desain penelitian pre test-post test with control group,
\end{abstract}


dengan jumlah sampel 32 ibu postpartum dengan bendungan ASI yang dibagi ke dalam dua kelompok (intervensi dan kontrol), teknik pengambilan sampel quota sampling, alat pengambilan data menggunakan lembar kuisioner berisi Six Point Engorgement Scale, Numeric Ratting Scale/NRS. Analisis data penelitian menggunakan uji Wilcoxon dan Mann-Whitney. Hasil penelitian menunjukkan kompres daun kubis dingin memiliki pengaruh bermakna terhadap penurunan skala pembengkakan, dan intensitas nyeri payudara serta peningkatan jumlah ASI dengan $p$-value masing-masing $0,000(\alpha<0,05)$, perah ASI juga memiliki pengaruh bermakna terhadap skala pembengkakan, intensitas nyeri, dan jumlah ASI dengan $p$-value $\alpha<0,05$. Terdapat perbedaan yang signifikan pada kedua kelompok dalam menurunkan skala bengkak dan intensitas nyeri ( $p$ value $<0,005)$, namun dalam peningkatan jumlah ASI tidak menunjukkan perbedaan yang signifikan antara kedua kelompok ( $p$-value 0,344$)$. Kesimpulan penelitian ini adalah kompres daun kubis dingin dapat digunakan sebagai terapi untuk menurunkan skala pembengkakan dan nyeri payudara pada ibu yang mengalami bendungan ASI.

Kata kunci: Skala pembengkakan payudara, Intensitas nyeri payudara, Jumlah ASI, Kompres daun kubis dingin, Perah ASI

*Korespondensi : Ervi Damayanti Surel: ervidamayanti@gmail.com

\section{PENDAHULUAN}

Upaya pemberian nutrisi terbaik pada anak dalam 2 tahun pertama kehidupannya merupakan suatu hal yang sangat penting bagi kesehatan, perkembangan dan kelangsungan hidup anak. ${ }^{1}$ Pemberian nutrisi yang optimal dapat ditunjang dengan beberapa hal yang direkomendasikan oleh WHO/UNICEF (2016), salah satunya adalah pemberian ASI eksklusif selama 6 bulan $^{(1)}$. Meskipun demikian, angka menyusui eksklusif pada bayi yang berusia 0-6 bulan di seluruh dunia, masih rendah yaitu sekitar 36\% selama periode 20072014(1).

Cakupan ASI eksklusif di Indonesia pada tahun 2013 masih belum memuaskan, yaitu berkisar antara 54,3\%, angka ini masih cukup jauh dari target nasional tahun 2013 sebesar $75 \%$. Sedangkan angka cakupan ASI eksklusif di Jawa Timur menurut laporan dinas kesehatan provinsi (2013) adalah sebesar $70,8 \%$. Angka tersebut sudah terbilang cukup tinggi, namun masih belum dapat mencapai target nasional 2013(2). Menurut dinas kesehatan Kabupaten Pasuruan (2015), cakupan ASI eksklusif di kabupaten Pasuruan adalah sebesar $68,8 \%$, dimana angka tersebut juga belum dapat mencapai target nasional(3).

Salah satu hal yang dapat menyebabkan hambatan dalam pemberian ASI eksklusif adalah adanya permasalahan pada

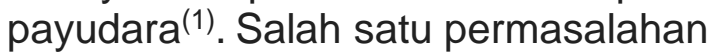
pada payudara yang sering terjadi adalah bendungan ASI atau pembengkakan Bendungan ASI merupakan pembendungan air susu karena penyempitan duktus laktiferus atau kelenjar-kelenjar yang tidak dikosongkan dengan sempurna. Pembengkakan payudara sering terjadi pada hari kedua sampai hari kesepuluh postpartum. Sebagian besar pasien merasakan payudara bengkak, merah, keras, nyeri dan terasa panas ${ }^{(4)}$. Penyebab bendungan ASI diantaranya tidak efektifnya frekuensi pengeluaran ASI, hal tersebut dapat disebabkan oleh beberapa hal, antara lain tidak 
dilakukannya rawat gabung sehingga terjadi pemisahan ibu dan anak, dan adanya teknik menyusui yang tidak benar dan efektif(5).

Menurut Data World Health Organization (WHO) terbaru pada tahun 2015 ibu yang mengalami bendungan ASI sebanyak 6.543 dari 9.862 orang(6). Hal ini disebabkan karena kesadaran masyarakat tentang peningkatan pemberian ASI masih rendah ${ }^{(7)}$. Sedangkan di RSUD Bangil sendiri kasus pembengkakan payudara atau bendungan ASI berdasarkan hasil observasi selama 6 hari di RSUD Bangil, didapatkan jumlah kasus bendungan ASI atau pembengkakan payudara sebanyak 62 kasus dari 107 ibu postpartum, jumlah tersebut tentunya tergolong cukup banyak.

Kubis atau kol (Brassica Oleracea Var. Capitata) merupakan sayuran ekonomis yang sangat mudah ditemukan. Kubis. mengandung asam amino glutamine yang diyakini dapat mengobati semua jenis peradangan, salah satunya radang yang terjadi pada payudara(8). Kubis juga kaya akan kandungan sulfur yang diyakini dapat mengurangi pembengkakan dan peradangan payudara ${ }^{(9)}$.

Berdasarkan penjabaran di atas peneliti tertarik untuk melakukan sebuah penelitian mengenai penggunaan kompres daun kubis dingin sebagai terapi pendamping bendungan ASI terhadap skala pembengkakan dan intensitas nyeri payudara, serta jumlah ASI pada ibu postpartum di RSUD Bangil.

\section{METODE PENELITIAN}

\section{Rancangan/Desain Penelitian}

Jenis penelitian ini adalah Quasy

Eksperimental dengan desain penelitian pre test-post test with control group. Di dalam desain ini terdapat dua kelompok, yaitu kelompok intervensi (diberi metode kompres daun kubis dingin dan perah ASI) dan kelompok kontrol (diberi metode perah ASI). Observasi pada masing-masing kelompok akan dilakukan dua kali, yaitu sebelum diberikan perlakuan/intervensi (pretest) dan sesudah diberikan perlakuan/intervensi (posttest) dalam waktu yang sudah ditentukan.

\section{Sampel Penelitian}

Sampel dalam penelitian ini adalah seluruh ibu postpartum dengan bendungan ASI yang memenuhi kriteria inklusi dan eksklusi. Pengambilan sampel dalam penelitian ini adalah dengan menggunakan non-random sampling dengan cara quota sampling Responden yang dipilih adalah dengan kriteria inklusi sebagai berikut: lbu postpartum hari ke-2 yang mengalami bendungan ASI, bersedia menjadi responden dengan menandatangi inform consent, dan tidak memiliki alergi daun kubis.

\section{Variabel Penelitian}

- Variabel independen dalam penelitian ini adalah penggunaan kompres daun kubis dingin.

- Variabel dependen dalam penelitian ini adalah skala pembengkakan dan intensitas nyeri payudara, serta jumlah ASI. 
Teknik Pengumpulan Data

Pengumpulan data dilakukan dengan teknik pengumpulan data secara primer yaitu peneliti melakukan wawancara dan observasi langsung kepada responden. Wawancara yang digunakan adalah wawancara terpimpin, yaitu wawancara yang dilakukan berdasarkan pertanyaan yang sesuai dengan lembar observasi (lembar observasi berisi skala pembengkakan yang diadopsi dari Hill dan Hummenick, 1994). Peneliti akan memberi pertanyaan dan menuliskan jawabkan responden ke dalam lembar observasi.

\section{Teknik Pemberian Kompres Daun Kubis Dingin}

Peneliti menyiapkan kubis yang telah dibeli dari satu tempat yang sama, kemudian memotong lembaran kubis dengan hati-hati dan mencucinya. Daun kubis dimasukkan ke dalam lemari pendingin selama 20-30 menit, lalu mengompreskan daun kubis dingin pada payudara ibu hingga menutupi seluruh permukaan payudara, selama 30 menit, perlakuan ini dilakukan sebanyak 3 kali dalam sehari.

\section{TEKNIK ANALISIS DATA}

Dalam menganalisis data digunakan program (SPSS) versi 16 sebagai alat bantu untuk mengolah data dengan tingkat signifikansi 0,005 $(p<0,05)$.

\section{HASIL PENELITIAN}

Jumlah responden yang berpartisipasi dalam penelitian ini adalah sebanyak 16 orang untuk masing-masing kelompok, dimana dalam penelitian ini keseluruhan responden merupakan ibu dengan hari ke-2 postpartum. Sebagian besar ibu postpartum di RSUD Bangil belum mendapatkan pelayanan rawat gabung secara maksimal, hal ini disebabkan metode persalinan di RSUD Bangil sebagian besar menggunakan metode sectio caesarea. Kurang efektifnya rawat gabung dapat menyebabkan kegiatan menyusui di awal masa nifas menjadi kurang efektif. Hal inilah yang menjadi salah satu faktor terjadinya bendungan ASI.

\section{Uji Univariat}

Tabel 1. Skala Pembengkakan Payudara Sebelum dan Sesudah Perlakuan pada Kedua Kelompok

\begin{tabular}{|c|c|c|c|c|c|c|c|c|c|c|c|c|}
\hline \multirow{4}{*}{$\begin{array}{c}\text { Skala } \\
\text { Pembengk } \\
\text { akan }\end{array}$} & \multicolumn{12}{|c|}{ Hasil Pengukuran Skala Pembengkakan } \\
\hline & \multicolumn{6}{|c|}{ Kelompok Intervensi } & \multicolumn{6}{|c|}{ Kelompok Kontrol } \\
\hline & \multicolumn{2}{|c|}{ Sebelum } & \multirow{2}{*}{$\begin{array}{l}\text { Rata- } \\
\text { rata }\end{array}$} & \multicolumn{2}{|c|}{ Setelah } & \multirow{2}{*}{$\begin{array}{l}\text { Rata- } \\
\text { rata }\end{array}$} & \multicolumn{2}{|c|}{ Sebelum } & \multirow{2}{*}{$\begin{array}{c}\text { Rata- } \\
\text { rata }\end{array}$} & \multicolumn{2}{|c|}{ Setelah } & \multirow{2}{*}{$\begin{array}{l}\text { Rata- } \\
\text { rata }\end{array}$} \\
\hline & $\mathbf{N}$ & $\%$ & & $\mathbf{N}$ & $\%$ & & $\mathbf{N}$ & $\%$ & & $\mathbf{N}$ & $\%$ & \\
\hline Skala 1 & 0 & 0 & \multirow{7}{*}{3,75} & 7 & 43,75 & \multirow{7}{*}{1,81} & 0 & 0 & \multirow{7}{*}{3,19} & 4 & 25 & \multirow{7}{*}{2,19} \\
\hline Skala 2 & 0 & 0 & & 6 & 37,50 & & 0 & 0 & & 7 & 43,75 & \\
\hline Skala 3 & 7 & 43,75 & & 2 & 12,50 & & 13 & 69,33 & & 3 & 18,75 & \\
\hline Skala 4 & 6 & 37,50 & & 1 & 6,25 & & 3 & 18,75 & & 2 & 12,50 & \\
\hline Skala 5 & 3 & 18,75 & & 0 & 0 & & 0 & 0 & & 0 & 0 & \\
\hline Skala 6 & 0 & 0 & & 0 & 0 & & 0 & 0 & & 0 & 0 & \\
\hline Total & 16 & 100 & & 16 & 100 & & 16 & 100 & & 16 & 100 & \\
\hline
\end{tabular}


Berdasarkan tabel 1 dapat dilihat bahwa sebelum diberikan tindakan kompres daun kubis dingin, sebagian besar responden mengalami pembengkakan payudara pada skala 3 , dimana dari 16 responden didapatkan rata-rata skala pembengkakan sebesar 3,75. Sedangkan, setelah pemberian tindakan kompres daun kubis dingin, seluruh responden mengalami penurunan skala pembengkakan, dengan rata-rata skala pembengkakan setelah perlakuan adalah sebesar 1,81.

Pada kelompok kontrol sebelum diberikan tindakan perah ASI, rata-rata skala pembengkakan payudara yang dialami adalah 3,19, namun setelah diberikan tindakan perah ASI, sebagian besar responden mengalami penurunan skala pembengkakan payudara, dengan rata-rata skala pembengkakan setelah perlakuan adalah 2,19.

Tabel 2. Intensitas Nyeri Payudara Sebelum dan Sesudah pada Kedua Kelompok

\begin{tabular}{|c|c|c|c|c|c|c|c|c|c|c|c|c|}
\hline \multirow{4}{*}{$\begin{array}{l}\text { Intensitas } \\
\text { Nyeri }\end{array}$} & \multicolumn{12}{|c|}{ Hasil Pengukuran Intensitas Nyeri } \\
\hline & \multicolumn{6}{|c|}{ Kelompok Intervensi } & \multicolumn{6}{|c|}{ Kelompok Kontrol } \\
\hline & \multicolumn{2}{|c|}{ Sebelum } & \multirow{2}{*}{$\begin{array}{l}\text { Rata- } \\
\text { rata }\end{array}$} & \multicolumn{2}{|c|}{ Setelah } & \multirow{2}{*}{$\begin{array}{l}\text { Rata } \\
\text {-rata }\end{array}$} & \multicolumn{2}{|c|}{ Sebelum } & \multirow{2}{*}{$\begin{array}{l}\text { Rata } \\
\text {-rata }\end{array}$} & \multicolumn{2}{|c|}{ Setelah } & \multirow{2}{*}{$\begin{array}{l}\text { Rata } \\
\text {-rata }\end{array}$} \\
\hline & $\mathbf{N}$ & $\%$ & & $\mathbf{N}$ & $\%$ & & $\mathbf{N}$ & $\%$ & & $\mathbf{N}$ & $\%$ & \\
\hline $\begin{array}{c}\text { Tidak Nyeri } \\
(0)\end{array}$ & 0 & 0 & \multirow{6}{*}{3,37} & 5 & 31,25 & \multirow{6}{*}{1,31} & 0 & 0 & \multirow{6}{*}{2} & 6 & 37,50 & \multirow{6}{*}{0,81} \\
\hline $\begin{array}{c}\text { Nyeri Ringan } \\
(1-3)\end{array}$ & 11 & 68,75 & & 10 & 62,50 & & 16 & 100 & & 10 & 62,50 & \\
\hline $\begin{array}{c}\text { Nyeri Sedang } \\
(4-6)\end{array}$ & 5 & 31,25 & & 1 & 6,25 & & 0 & 0 & & 0 & 0 & \\
\hline $\begin{array}{c}\text { Nyeri Berat } \\
(7-9)\end{array}$ & 0 & 0 & & 0 & 0 & & 0 & 0 & & 0 & 0 & \\
\hline $\begin{array}{c}\text { Nyeri sangat } \\
\text { Berat (10) }\end{array}$ & 0 & 0 & & 0 & 0 & & 0 & 0 & & 0 & 0 & \\
\hline Total & 16 & 100 & & 16 & 100 & & 16 & 100 & & 16 & 100 & \\
\hline
\end{tabular}

Berdasarkan tabel 2 dapat dilihat bahwa sebelum diberikan tindakan kompres daun kubis dingin didapatkan rata-rata intensitas nyeri sebesar 3,37. Sedangkan, setelah pemberian tindakan kompres daun kubis dingin, seluruh responden mengalami penurunan intensitas nyeri, dengan rata-rata intensitas setelah perlakuan adalah sebesar 1,31 .
Pada kelompok kontrol sebelum diberikan tindakan perah ASI, rata-rata intensitas nyeri adalah sebesar 2, namun setelah diberikan tindakan perah ASI, sebagian besar responden mengalami penurunan intensitas nyeri payudara, dengan rata-rata intensitas nyeri setelah perlakuan adalah 0,81 . 
Tabel 3 Jumlah ASI Sebelum dan Sesudah pada Kedua Kelompok

\begin{tabular}{|c|c|c|c|c|c|c|c|c|c|c|c|c|}
\hline \multirow{4}{*}{$\begin{array}{c}\text { Jumlah ASI } \\
(\mathrm{ml})\end{array}$} & \multicolumn{12}{|c|}{ Hasil Pengukuran Jumlah ASI } \\
\hline & \multicolumn{6}{|c|}{ Kelompok Intervensi } & \multicolumn{6}{|c|}{ Kelompok Kontrol } \\
\hline & \multicolumn{2}{|c|}{ Sebelum } & \multirow{2}{*}{$\begin{array}{l}\text { Rata } \\
\text {-rata } \\
\text { (ml) }\end{array}$} & \multicolumn{2}{|c|}{ Setelah } & \multirow{2}{*}{$\begin{array}{c}\text { Rata- } \\
\text { rata } \\
\text { (ml) }\end{array}$} & \multicolumn{2}{|c|}{ Sebelum } & \multirow{2}{*}{$\begin{array}{l}\text { Rata } \\
\text {-rata }\end{array}$} & \multicolumn{2}{|c|}{ Setelah } & \multirow{2}{*}{$\begin{array}{c}\text { Rata- } \\
\text { rata }\end{array}$} \\
\hline & $\mathbf{N}$ & $\%$ & & $\mathbf{N}$ & $\%$ & & $\mathbf{N}$ & $\%$ & & $\mathbf{N}$ & $\%$ & \\
\hline 0 & 5 & 31,25 & \multirow{7}{*}{0,09} & 0 & 0 & \multirow{7}{*}{0,28} & 5 & 31,25 & \multirow{7}{*}{0,15} & 0 & 0 & \multirow{7}{*}{0,26} \\
\hline $0,01-0,04$ & 3 & 18,75 & & 2 & 12,5 & & 2 & 12,5 & & 3 & 18,75 & \\
\hline $0,05-0,09$ & 2 & 12,5 & & 4 & 25 & & 1 & 6,25 & & 2 & 12,5 & \\
\hline 0,1 & 3 & 18,75 & & 2 & 12,5 & & 3 & 18,75 & & 4 & 25 & \\
\hline 0,2 & 0 & 0 & & 1 & 6,25 & & 2 & 12,5 & & 2 & 12,5 & \\
\hline 0,3 & 2 & 12,5 & & 3 & 18,75 & & 1 & 6,25 & & 2 & 12,5 & \\
\hline$\geq 0,4$ & 1 & 6,25 & & 4 & 25 & & 2 & 12,5 & & 3 & 18,75 & \\
\hline Total & 16 & 100 & & 16 & 100 & & 16 & 100 & & 16 & 100 & \\
\hline
\end{tabular}

Berdasarkan tabel 3 dapat dilihat bahwa sebelum diberikan tindakan kompres daun kubis dingin, rata-rata jumlah ASI yang dikeluarkan sebesar 0,09 . Sedangkan, setelah pemberian tindakan kompres daun kubis dingin, sebagian besar responden mengalami peningkatan jumlah ASI, dengan rata-rata jumlah ASI setelah perlakuan adalah sebesar 0,28.

Pada kelompok kontrol sebelum diberikan tindakan perah ASI, rata-rata jumlah ASI yang dikeluarkan adalah 0,15 , namun setelah diberikan tindakan perah ASI, sebagian besar responden mengalami peningkatan jumlah ASI, dengan rata-rata jumlah ASI setelah pemberian perlakuan adalah 0,26.

\section{Uji Bivariat}

Berdasarkan hasil uji normalitas di atas dengan menggunakan uji Saphiro-Wilk, didapatkan bahwa untuk semua variabel pada kedua kelompok memiliki data yang tidak berdistribusi normal. Hal tersebut dapat dilihat berdasarkan nilai signifikansi pada saat sebelum dan sesudah pemberian tindakan, yaitu kurang dari $0,05(<0,05)$, sehingga data hasil penelitian dianalisis dengan menggunakan uji nonparametrik yaitu dengan uji Wilcoxon dan Mann Whitney.

Tabel 4 Perbedaan Hasil Skala Pembengkakan Payudara, Intensitas Nyeri Payudara, dan Jumlah ASI Sebelum Dan Sesudah Pemberian Perlakuan pada Kedua Kelompok dengan Uji Wilcoxon.

\begin{tabular}{|c|c|c|c|c|c|c|c|c|}
\hline \multirow{2}{*}{ Variabel } & \multicolumn{2}{|c|}{ Kelompok Intervensi } & \multirow{2}{*}{ Delta } & \multirow{2}{*}{$\begin{array}{c}p- \\
\text { value }\end{array}$} & \multicolumn{2}{|c|}{ Kelompok Kontrol } & \multirow{2}{*}{ Delta } & \multirow{2}{*}{$\begin{array}{c}p- \\
\text { value }\end{array}$} \\
\hline & Sebelum & Sesudah & & & Sebelum & Sesudah & & \\
\hline $\begin{array}{c}\text { Skala } \\
\text { Pembengkakan }\end{array}$ & 3,75 & 1,81 & 1,94 & 0,000 & 3,19 & 2,19 & 1 & 0,003 \\
\hline $\begin{array}{c}\text { Intensitas } \\
\text { Nyeri }\end{array}$ & 3,37 & 1,31 & 2,06 & 0,000 & 2 & 0,81 & 1,19 & 0,001 \\
\hline Jumlah ASI & 0,09 & 0,28 & 0,19 & 0,000 & 0,15 & 0,26 & 0,11 & 0,000 \\
\hline
\end{tabular}

Berdasarkan tabel 4 dapat dilihat bahwa pada kelompok kompres daun kubis dingin (kelompok intervensi) menunjukkan bahwa nilai p-value untuk penurunan skala pembengkakan sebesar 0,000, p-value untuk penurunan intensitas nyeri sebesar 0,000 , dan $p$ value untuk peningkatan jumlah ASI adalah 
0,000 dimana nilai $p$ dari ketiga variabel < $\alpha(0,05)$. Hal ini membuktikan bahwa terdapat perbedaan yang signifikan pada ketiga variabel antara nilai sebelum dan sesudah pemberian perlakuan pada kelompok kompres daun kubis dingin.

Pada kelompok perah ASI (kelompok kontrol) menunjukkan bahwa nilai $p$-value untuk penurunan skala pembengkakan sebesar 0,003, p-value untuk penurunan intensitas nyeri sebesar 0,001 , dan $p$-value untuk peningkatan jumlah ASI adalah 0,000 dimana nilai $p$ dari ketiga variabel < $\alpha(0,05)$. Hal ini membuktikan bahwa terdapat perbedaan yang signifikan pada ketiga variabel antara nilai sebelum dan sesudah pemberian perlakuan pada kelompok perah ASI.

Tabel 5 Perbedaan Perubahan Skala Pembengkakan, Intensitas Nyeri Payudara, Dan Jumlah ASI Setelah Perlakuan Pada Kedua Kelompok Dengan Uji Mann Whitney

\begin{tabular}{cccc}
\hline Variabel & Kelompok & $\begin{array}{c}\text { Rerata Perubahan } \\
\text { (Delta) }\end{array}$ & P-value \\
\hline $\begin{array}{c}\text { Pembengkakan } \\
\text { Payudara }\end{array}$ & Intervensi & 1,94 & 0,005 \\
\cline { 2 - 3 } & Kontrol & 1 & 0 \\
\hline \multirow{2}{*}{ Intensitas Nyeri } & Intervensi & 2,06 & 0,002 \\
\cline { 2 - 3 } & Kontrol & 1,19 & \multirow{2}{*}{0,344} \\
\hline \multirow{2}{*}{ Jumlah ASI } & Intervensi & $0,19 \mathrm{ml}$ & \\
\cline { 2 - 3 } & Kontrol & $0,11 \mathrm{ml}$ & \\
\hline
\end{tabular}

Berdasarkan tabel 5 dapat dilihat bahwa untuk perbandingan kedua kelompok dengan uji Mannwithney, menunjukkan skala pembengakan memiliki nilai $p$ sebesar 0,005 dan untuk intensitas nyeri memiliki nilai $p$ sebesar 0,002 , dimana nilai $p<a(0,05)$. Dapat disimpulkan bahwa pemberian kompres daun kubis dingin memiliki perbedaan yang signifikan dalam menurunkan skala pembengkakan dan intensitas nyeri payudara, bila dibandingkan dengan perlakukan perah ASI. Namun, untuk jumlah ASI yang diperoleh menunjukkan nilai $p$ sebesar 0,344 dimana nilai $p$ $>$ a $(0,05)$. Dapat disimpulkan bahwa pemberian kompres daun kubis dingin tidak memiliki perbedaan yang signifikan dengan pemberian perlakuan perah ASI.

\section{PEMBAHASAN \\ Karakteristik Dasar Responden}

Hasil penelitian ini diketahui bahwa responden yang berpartisipasi dalam penelitian ini adalah ibu yang mengalami bendungan ASI pada hari ke-2 postpartum, sebelumnya telah dilakukan penelitian mengenai bendungan $\mathrm{ASI}$, dimana sebagian besar sampel yang diambil adalah ibu-ibu pada minggu pertama pasca persalinan. Penelitian Kumari et al (2016) didapatkan bahwa dari 32 sampel ibu postpartum yang mengalami bendungan ASI, terdapat 28 atau $(87 \%)$ ibu hari $2-4$ 
postpartum(10). Hasil yang hampir serupa juga didapatkan dari penelitian Lim et al (2015) mengenai bendungan ASI/pembengkakan payudara, dimana diketahui bahwa keseluruhan responden yang terlibat dalam penelitian tersebut adalah ibu-ibu postpartum hari ke-2 hingga keempat ${ }^{(11)}$.

Penelitian lain dilakukan oleh Novita (2011), dimana dalam penelitian tersebut yang menjadi kriteria inklusi adalah ibu postpartum hari ke-2 hingga ke-5 yang biasa mengalami bendungan ASI. $^{12}$ Minggu pertama pasca bersalin memang menjadi waktu yang sering ditemukan kejadian bendungan ASI. Menurut Mansyur (2014) payudara bengkak atau bendungan ASI biasa terjadi pada hari-hari awal setelah ibu bersalin. Statis pada pembuluh darah dan limfe akan mengakibatkan meningkatnya tekanan intraduktal, yang akan mempengaruhi berbagai segmen pada payudara, sehingga tekanan pada payudara dapat meningkat. Akibatnya payudara akan terasa penuh, tegang dan nyeri(13).

Keseluruhan responden

merupakan ibu postpartum yang belum dilakukan metode rawat gabung dengan maksimal, dimana menurut beberapa teori, salah satu etiologi terjadinya bendungan ASI adalah adanya bayi yang tidak menyusu secara efektif dan efisien sehingga membuat ASI masih bersisa di dalam payudara, menahan atau terlambatnya pengeluaran ASI dapat menyebabkan distensi alveolar ${ }^{(14)}$. Mass (2004) menyebutkan bahwa bendungan ASI dapat disebabkan oleh karena tidak efektifnya frekuensi pengeluaran ASI, dimana etiologi tersebut dapat terjadi akibat dari tidak dilakukannya rawat gabung sehingga terjadi pemisahan ibu dan anak(5).

\section{Perbedaan Skala Pembengkakan Payudara, Intensitas Nyeri Payudara, dan Jumlah ASI Sebelum Dan Sesudah Pemberian Perlakuan pada Kedua Kelompok} Penelitian ini dilakukan selama satu hari, dengan memberikan perlakuan sebanyak 3 kali dalam sehari yaitu pagi, siang, dan sore. Hasil penelitian ini menunjukkan bahwa sebelum pemberian perlakuan sebagian besar responden hanya mengalami pembengkakan pada skala tengah (skala 3 sampai 4). Menurut Hill dan Hummenick (1994) skala 3 pada six point engorgement scale menunjukkan adanya pembengkakan payudara namun masih dalam tahap awal. Kemudian, skala 4 pada six point engorgement scale menunjukkan adanya pembengkakan payudara yang lebih parah bila dibandingkan dengan skala $3^{(14)}$. Sehingga rasa nyeri yang disebutkan oleh responden juga cenderung ringan yaitu berkisar antara skala 2 hingga 4. Sedangkan untuk jumlah ASI sebelum pemberian perlakuan pada kedua kelompok didapatkan jumlah ASI yang masih sangat sedikit, hal ini dapat terjadi mengingat pada ibu yang mengalami bendungan ASI biasanya terjadi sumbatan pada pembuluh darah vena dan limfe, yang nantinya dapat menyebabkan sumbatan pada aliran air susu(13), sehingga menyebabkan ASI terjebak di dalam saluran susu payudara dan jumlah ASI yang keluar juga relatif lebih sedikit.

Berdasarkan hasil penelitian ini dapat diketahui bahwa pemberian kompres daun kubis 
dingin dan juga perlakuan perah ASI pada responden mampu memberikan efek yang baik dalam menurunkan skala pembengkakan dan intensitas nyeri payudara, serta meningkatkan jumlah ASI. Hasil uji Wilcoxon untuk ketiga variabel (skala pembengkakan, intensitas nyeri, dan jumlah $\mathrm{ASI}$ ) antara nilai sebelum dan sesudah diberikan perlakuan pada kelompok kompres daun kubis dingin menunjukkan nilai $p$-value untuk penurunan skala pembengkakan sebesar $0,000, p$ value untuk penurunan intensitas nyeri sebesar 0,000 , dan $p$-value untuk peningkatan jumlah ASI adalah 0,000 . Sedangkan pada kelompok kontrol didapatkan nilai $p$ value dari ketiga variabel pada kedua kelompok tersebut adalah $<\alpha$ $(0,05)$. Hal ini membuktikan bahwa terdapat perbedaan yang signifikan pada ketiga variabel antara nilai sebelum dan sesudah pemberian perlakuan pada kedua kelompok.

Hasil penelitian ini dapat dikatakan sesuai dengan penelitian yang dilakukan oleh Disha et al (2015), dimana dalam penelitiannya Disha et al memperoleh hasil bahwa pemberian kompres daun kubis dingin mampu menurunkan skala pembengkakan sebanyak 2 dengan $p$-value $<0,01^{(15)}$. Dimana penurunan tersebut juga didapatkan setelah 3 kali pemberian intervensi daun kubis dingin. Hasil tersebut juga didukung oleh beberapa teori, yaitu menurut Lim et al: 2015 pemberian kompres daun kubis dingin mampu meringankan edema pada kesleo ataupun fraktur termasuk adanya edema pada pembengkakan payudara(11). Menurut Lim et al (2015) sebenarnya belum diketahui dengan jelas kandungan dalam daun kubis apa yang berpengaruh terhadap pembengkakan ${ }^{(11)}$. Namun, dalam beberapa penelitian lain disebutkan bahwa kubis merupakan suatu terapi yang tepat digunakan dalam mengatasi

pembengkakan payudara, di antaranya penelitian yang dilakukan oleh Ayers (2000), dan penelitian oleh Arora et al tahun 2008, menyebutkan bahwa memang kompres daun kubis telah terbukti efektif dan ekonomis dalam meredakan pembengkakan payudara tanpa disertai efek samping ${ }^{(16,17)}$. Menurut Dalimartha (2005), daun kubis mengandung asam amino glutamine yang diyakini dapat mengobati semua jenis peradangan, salah satunya radang yang terjadi pada payudara(18). Kubis dapat digunakan sebagai terapi luar dengan cara pengompresan pada bagian tubuh yang membengkak ataupun terasa nyeri. Kandungan sulfur yang tinggi pada kubis juga diyakini dapat mengurangi pembengkakan dan peradangan pada payudara ${ }^{(9)}$. Daun kubis hijau (brasica capitata) mengandung zat sulphure, dimana adanya zat tersebut membuat daun kubis memiliki sifat antibiotik dan anti-inflamasi, yang dapat membantu memperlebar (vasodilatasi) pembuluh darah kapiler, sehingga akan meningkatkan aliran darah untuk keluar masuk dari daerah tersebut ${ }^{(19)}$. Penelitian lain yang meneliti terkait metode perah ASI adalah penelitian yang dilakukan oleh Lim et al (2015), dimana dalam penelitiannya terkait efektifitas kompres daun kubis dan perawatan awal payudara terhadap bendungan ASI, Lim memperoleh hasil bahwa pemberian treatment perawatan payudara di awal masa nifas yang 
mana salah satu treatment yang diberikan adalah pemerahan payudara, ternyata mampu menurunkan rasa nyeri dengan signifikansi sebesar 0,016, dan untuk penurunan skala pembengkakan memiliki signifikansi sebesar $0,001^{(11)}$. Perah ASI adalah suatu metode yang biasa dilakukan untuk meringankan bendungan ASI, dimana menurut Smith and Tully (2001) disebutkan bahwa salah satu cara untuk mengurangi pembengkakan payudara atau bendungan ASI adalah dengan cara mengeluarkan ASI sedikit demi sedikit untuk membuat daerah sekitar areola lebih lembek ${ }^{(20)}$. Dengan perah ASI atau hisapan bayi ini diharapkan payudara akan dapat kosong dan bendungan ASI dapat segera membaik.

\section{Perbedaan Perubahan Skala Pembengkakan, Intensitas Nyeri Payudara, dan Jumlah ASI setelah Perlakuan pada Kedua Kelompok}

Berdasarkan uji Mann Whitney yang telah dilakukan, diperoleh hasil bahwa perbedaan penurunan skala pembengkakan pada kedua kelompok menunjukkan $p$-value sebesar 0,005 atau nilai $p<$ $\alpha(0,05)$. Hal tersebut menunjukkan bahwa tedapat perbedaan yang signifikan setelah pemberian perlakuan pada kedua kelompok terhadap penurunan skala pembengkakan. Selanjutnya, untuk variabel intensitas nyeri diperoleh hasil bahwa perbedaan penurunan intensitas nyeri pada kedua kelompok menunjukkan $p$-value sebesar 0,002 atau nilai $p<\alpha$ $(0,05)$. Hal tersebut menunjukkan bahwa tedapat perbedaan yang signifikan setelah pemberian perlakuan pada kedua kelompok terhadap penurunan intensitas. Kemudian, pada variabel yang ketiga yaitu jumlah ASI diperoleh hasil bahwa perbedaan peningkatan jumlah ASI pada kedua kelompok menunjukkan $p$-value sebesar 0,344 atau nilai $p>\alpha(0,05)$. Hal tersebut menunjukkan bahwa tidak terdapat perbedaan yang signifikan setelah pemberian perlakuan pada kedua kelompok terhadap peningkatan jumlah ASI.

Berdasarkan hasil penelitian ini dapat disimpulkan bahwa kedua perlakuan tersebut dapat diberikan pada ibu yang mengalami bendungan ASI untuk mengatasi ketidaknyamanan akibat bendungan ASI. Penelitian menunjukkan bahwa dengan perah ASI atau metode mengosongkan payudara sudah mampu untuk mengatasi ketidaknyamanan akibat bendungan ASI, namun untuk mendapatkan hasil yang lebih baik, selain memberikan perlakuan perah ASI, metode yang tepat untuk ditambahkan adalah dengan memberikan perlakuan berupa kompres daun kubis dingin.

Hasil yang didapatkan dalam penelitian ini didukung oleh beberapa penelitian yang lain, di antaranya adalah penelitian yang dilakukan oleh Novita (2011) efektifitas kompres daun kol terhadap rasa nyeri, pembengkakan payudara dan produksi ASI pada ibu postpartum, disebutkan dalam penelitian tersebut bahwa pemberian kompres daun kol mampu menurunkan nyeri serta pembengkakan payudara dengan $p$ value masing-masing sebesar $0,0005^{(12)}$. Namun, untuk produksi 
ASI didapatkan hasil bahwa kompres daun kol tidak menunjukkan hubungan yang signifikan dalam produksi ASI dengan $p$-value $0,32^{(12)}$.

Penelitian yang dilakukan oleh Astutik dkk (2016) mengenai pengaruh kompres daun kubis dingin terhadap skala pembengkakan payudara di kecamatan Bergas, didapatkan hasil bahwa pemberian kompres daun kubis dingin mampu menurunkan skala pembengkakan payudara sebesar 2,83 dengan p-value $0,000^{(21)}$. Pemberian kompres daun kubis dingin tersebut lebih efektif bila dibandingkan dengan pemberian plasebo berupa tepung terigu, dengan $p$-value $0,000^{(21)}$.

Pemberian perlakuan perah ASI ditambah dengan kompres daun kubis dingin maupun pemberian perlakuan perah ASI saja merupakan metode yang samasama efektif dalam menangani bendungan ASI. Namun, pemberian kompres daun kubis dingin ditambah dengan perah ASI dirasa lebih efektif dalam mengatasi ketidaknyaman akibat bendungan ASI. Hal tersebut dapat diketahui bahwa kompres daun kubis dingin mampu memberikan rasa nyaman pada payudara ibu sehingga akan mempengaruhi persepsi ibu terhadap rasa nyeri, dan rasa nyeri akan dirasakan lebih ringan. Selain itu pemberian kompres daun kubis dingin merupakan metode yang dirasa sangat efektif dan ekonomis karena daun kubis merupakan sayuran yang murah, mudah ditemukan, dan tidak memberikan efek samping bila digunakan sebagai kompres. Hal tersebut sesuai dengan pernyataan Jung (2004) dalam penelitiannya mengenai perubahan pembengkakan payudara setelah pemberian kompres daun kubis dingin, dimana dalam penelitian tersebut disimpulkan bahwa kompres kubis merupakan metode yang tepat, efektif, murah, serta tidak memiliki efek samping dalam mengatasi bendungan $A S^{(22)}$. Sehingga dapat terjangkau oleh seluruh kalangan ibu-ibu yang mengalami pembengkakan payudara atau bendungan ASI.

Pemberian kompres daun kubis dingin ditambah perah ASI bila dibandingkan dengan pemberian perah ASI saja, memang menunjukkan perbedaan signifikansi dalam meringankan pembengkakan dan juga intensitas nyeri pada payudara, namun ternyata pemberian kompres daun kubis dingin ini memiliki signifikansi yang sama dalam meningkatkan jumlah ASI, bila dibandingkan dengan pemberian perah ASI saja. Hasil yang didapatkan dalam penelitian ini didukung oleh penelitian lain yang dilakukan oleh Novita (2011) mengenai efektifitas kompres daun kol terhadap rasa nyeri, pembengkakan payudara dan produksi ASI pada ibu postpartum, disebutkan dalam penelitian tersebut bahwa pemberian kompres daun kol tidak menunjukkan hubungan yang signifikan dalam produksi ASI dengan p-value 0,32. Berdasarkan beberapa teori, hal tersebut dapat terjadi dikarenakan daun kubis tidak mengandung suatu zat yang mampu meningkatkan produksi ASI, daun kubis hanya mengandung zat yang diprediksi mampu memperlebar pembuluh darah untuk meningkatkan aliran darah sehingga aliran ASI yang semula tersumbat menjadi lebih 
lancar, hal ini yang diduga mampu membuat ASI yang diperoleh lebih banyak setelah intervensi diberikan ${ }^{(23,24)}$.

\section{Keterbatasan Penelitian}

Penelitian ini hanya dilakukan pada ibu yang mengalami bendungan ASI pada hari kedua postpartum saja, penelitian ini hanya dilakukan dalam waktu 1 hari, tingkatan rasa nyeri yang dirasakan oleh responden masih subjektif, meskipun sudah menggunakan alat ukur dengan beberapa tingkatan dan karakteristik nyeri, penelitian ini tidak mengkaji berapa lama waktu yang diperlukan hingga didapatkan efek yang maksimal dari intervensi yang diberikan.

\section{SIMPULAN}

Pemberian kompres daun kubis dingin memiliki perbedaan yang signifikan dalam menurunkan skala pembengkakan dan intensitas nyeri payudara, bila dibandingkan dengan perlakukan perah ASI dengan nilai $p$ sebesar 0,005 dan untuk intensitas nyeri memiliki nilai $p$ sebesar 0,002 , dimana nilai $p<\alpha$ $(0,05)$. Namun, untuk jumlah ASI yang diperoleh menunjukkan nilai $p$ sebesar 0,344 dimana nilai $p>\alpha$ $(0,05)$, dapat disimpulkan bahwa pemberian kompres daun kubis dingin tidak memiliki perbedaan yang signifikan dengan pemberian perlakuan perah ASI.

\section{Daftar pustaka}

1. WHO. 2016. Infant and young child feeding. Media centre.

2. Kemenkes RI. 2014. Situasi dan Analisis ASI Eksklusif. Pusat Data dan Informasi Kementerian Kesehatan RI. Jakarta. hal. 1-2.
3. Dinkes Kabupaten Pasuruan. 2015. Profil Kesehatan Pasuruan Tahun 2015.

4. Pitriani, Risa. 2014. Panduan Lengkap Asuhan Kebidanan Ibu Nifas Normal (Askeb III). Yogyakarta: deepublish.Mass, Sharon. 2004. Breast Pain: Engorgement, Nipple Pain, and Mastitis. Clinical Obstetrics and Gynecology. 47 (3): 676-682.

5. Depkes RI. 2014. Profil Kesehatan Kalimantan Selatan.

6. Dalimartha, $S$ dan Adrian, $F$. 2011. Khasiat Buah dan Sayur. Jakarta : Penebar Swadaya Grup.

7. Green, Wendy. 2015. The New Parents' Survival Guide: The First Three Months. Chicester: Summersdale Publishers.

8. Kumari, Rekha. 2016. Effectiveness of Green Cabbage Leaves (GCL) and Hot Water Bag (HWB) Application on Breast Engorgement in Postnatal Mothers. Obstetrics and Gynecology Nursing. 5(1), 28-31.

9. Lim, A-reum, et al. 2015. Cabbage Compression Early Breast Care on Breast Engorgement in Primiparous Women After Cesarean Birth: a Controlled Clinical Trial. Int $\mathrm{J}$ Clin Exp Med. 8 (11).

10. Novita, R V T. 2011. Efektivitas Paket "Bunda Ceria" terhadap Rasa Nyeri dan Pembengkakan Payudara serta Produksi ASI pada Ibu Postpartum di Jakarta. Jakarta: Universitas Indonesia.

11. Mansyur, Nurliana., Dahlan, Kasrinda. 2014. Asuhan kebidanan Masa Nifas. Malang: Saleksa Medika.

12. Hill, PD., Humenick, SS. 1994. The Occurrence of Breast 
Engorgement. J Hum Lact. 10(2). 80.

13. Disha, el al. 2015. Effect of chilled cabbage leaves vs. hot compression on breast engorgement among post natal mothers admitted in a tertiary care hospital. Nursing and Midwifery Research Journal, Vol-11, No. 1.

14. Ayers JF. 2000. The use of Alternatif Therapies in the Support of Breastfeeding. J Hum Lact. 16:52-56.

15. Arora, S., et al. 2008. A Comparison of Cabbage Leaves vs Hot and Cold Compresses In the treatment of Breast Engorgement. Indian Journal of Community Medicine. 33 (3), 160-162.

16. Dalimartha, S. 2005. Atlas tumbuhan Obat Indonesia, jilid 2. Jakarta: Trubus Agriwidya.

17. Mars, Briggite., Fiedler, Chrystle. 2014. The Country Almanac of Home Remedies: Time-tested and Almost Forgotten Wisdom for Treating Hundreds of Common Ailments, Aches \& Pains Qickly and Naturally. Beverly: Fair Winds Press.

18. Smith, J W., Tully M R. 2001. Midwifery Management of Breastfeeding: Using the
Evidence. Journal of Midwifery \& Women's Health. 46 (6), 423438.

19. Astutik, E Z., dkk. 2016. Pengaruh Pemberian Kompres Daun Kubis Dingin Tehadap Skala Pembengkakan Payudara Pada Ibu Postpartum Dengan Engorgement di Kecamatan Bergas. STIKES Ngudi Waluyo Ungaran.

20. Jung SH. 2004. The Change of Breast Engorgement fot nonGreast Feeding Mother After Cold Cabbage Compress. Unpublished Master Thesis.

21. Wahyuni, Elly., dkk. 2012. Pengaruh Konsumsi Jantung Pisang Batu terhadap Peningkatan Produksi ASI di Wilayah Puskesmas Srikuncoro, Kecamatan Pondok Kelapa, Bengkulu Tengah Tahun 2012. Buletin Penelitian Sistem Kesehatan, Vol. 15 No. 4 Oktober 2012.

22. Subekti. 2006. Penggunaan Tepung Daun Katuk Dan Ekstrak Daun Katuk (Sauropus Androgynus) Sebagai Substitusi Ransum Yang Dapat Menghasilkan Produk Puyuh Jepang Yang Rendah Kolesterol. Bogor: Fakultas peternakan IPB. 